\title{
Characterization of abamectin resistance in Iranian populations of European red mite, Panonychus ulmi Koch (Acari: Tetranychidae)
}

Fariborz Rameshgar ${ }^{\mathrm{a}}$, Jahangir Khajehali ${ }^{\mathrm{a},{ }^{*}}$, Ralf Nauen ${ }^{\mathrm{b}}$, Wannes Dermauw ${ }^{\mathrm{c}}$, Thomas Van Leeuwen ${ }^{\mathrm{c}, *}$

${ }^{a}$ Department of Plant Protection, College of Agriculture, Isfahan University of Technology, Isfahan 8415683111, Iran.

b Bayer AG, CropScience Division, R\&D, Pest Control, Building 6260, Alfred Nobel Str. 50, D-40789 Monheim, Germany.

${ }^{c}$ Laboratory of Agrozoology, Department of Plants and Crops, Faculty of Bioscience Engineering, Ghent University, Coupure links 653, 9000, Ghent, Belgium

* Corresponding authors:

Jahangir Khajehali (khajeali@cc.iut.ac.ir) and Thomas Van Leeuwen (thomas.vanleeuwen@ugent.be) 


\section{Abstract}

The European red mite, Panonychus ulmi Koch is one of the most important pests in apple orchards and was introduced to Iran by apple seedlings from Europe. The insecticide/acaricide abamectin for example has been used extensively against P. ulmi and some other pests in apple orchards. To evaluate abamectin resistance in field-collected populations of P. ulmi, 12 populations were collected from commercial apple orchards of East Azarbaijan, West Azarbaijan, and Isfahan provinces. The abamectin toxicity was determined by a leaf disc spray method. The $\mathrm{LC}_{50}$ values of abamectin ranged from $0.11 \mathrm{mg}$ a.i. $\mathrm{L}^{-1}$ to $5.50 \mathrm{mg}$ a.i. $\mathrm{L}^{-1}$. All field populations were resistant to abamectin (RR ranged from 11- to 46-fold) in comparing with PSR-TK, a reference susceptible population for abamectin. The Mahabd population was identified as the most resistant population. The glutamate-gated chloride channels (GluCls) are well-known target site of abamectin in mites and it was demonstrated that amino acid substitutions in GluCls can confer abamectin resistance. The partial channels PuGluCl1, PuGluCl2, and PuGluCl3 were sequenced in Mahabad population, but the previously reported point mutations associated with abamectin resistance in Tetranychus urticae Koch were not found. In contrast, the cytochrome P450 monooxygenase inhibitor piperonyl butoxide (PBO) significantly increased abamectin toxicity in Mahabad (synergistic ratio $\mathrm{SR}=64$ ), a moderately resistant population, and Shahin Dej $(\mathrm{SR}=2$ ) population. Also, pretreatment of triphenylphosphate (TPP) resulted in reduced $\mathrm{LC}_{50}$ values of abamectin in Shahin Dej (SR $=4.79)$ and Mahabad $(\mathrm{SR}=8.91)$ populations. The second highest synergism ratio $(\mathrm{SR}=22.13)$ against abamectin was observed in the resistant population of Mahabad with the glutathione S-transferase inhibitor diethylmaleate (DEM). Although quantification of activity of detoxification enzymes with model substrates did not support the role of detoxification enzymes, the synergism assays and the lack of target-site resistance suggested that multiple metabolic mechanisms are involved in abamectin resistance.

Keywords: Panonychus ulmi, Abamectin resistance, Detoxification

\section{Introduction}

The European red mite, Panonychus ulmi Koch (Acari: Tetranychidae), is one of the economically most important tetranychid mites in agriculture (Van Leeuwen et al., 2015). This mite species is especially destructive for apple trees and other plant species from the Rosaceae family (Jeppson et al., 1975). P. ulmi is not native in Iran, but was introduced via the import of apple seedlings from Europe (Behdad, 1991; Arbabi et al., 2004). Control of $P$. ulmi and other phytophagous mites is mostly dependent on frequent acaricide applications 
(Van Leeuwen et al., 2013; Van Leeuwen et al., 2015). As well as specific acaricides, some broad-spectrum insecticides are also used for mite control (Van Leeuwen et al., 2015; Van Leeuwen et al., 2010). Macrocyclic lactones such as avermectins and milbemycins have potent insecticidal and acaricidal activity (Wolstenholme and Rogers, 2005; Wolstenholme, 2010, 2012a, b). Abamectin, a well-kwon insecticide/acaricide, is a mixture of avermectins B ${ }_{1 \mathrm{a}}$ and $\mathrm{B}_{1 \mathrm{~b}}$ (Sparks and Nauen, 2015; Van Leeuwen et al., 2015).

The high acaricide selection pressure on $P$. ulmi and other spider mites has led to the development of resistance to several commercially available acaricides (Bajda et al., 2015; Kramer and Nauen, 2011; Rameshgar et al., 2019; Van Leeuwen et al., 2010; Whalon et al., 2012). In phytophagous mites, different factors have been associated with the rapid development of acaricide resistance, including the frequent use of acaricides, arrhenotokous reproduction, high fecundity, short life cycle, and in some cases the evolutionary history of the mite species (Dermauw et al., 2013; Van Leeuwen et al., 2010). However, acaricide resistance may present some fitness costs with negative effects on the life history traits of resistant mites, providing opportunities for resistance management (Bajda et al., 2018).

The glutamate-gated chloride channels (GluCls) are the main target site of abamectin (Ozoe, 2013; Wolstenholme and Rogers, 2005; Wolstenholme, 2010). Recent studies have revealed that the two-spotted spider mite T. urticae has five to six $\mathrm{GluCl}$ orthologs, while insects have only a single GluCl gene (Dermauw et al., 2012; Van Leeuwen and Dermauw, 2016). In P. ulmi, five orthologous $\mathrm{GluCl}$ genes were found (PuGluCl1, PuGluCl2, PuGluCl3, PuGluCl4, and PuGluCl5) (Bajda et al., 2015). It was suggested that the functional diversity of GluCls is associated with the copy number in mites, while this is achieved by alternative splicing of mRNA in insects (Dermauw et al., 2012; Van Leeuwen and Dermauw, 2016; Wang et al., 2019).

Abamectin resistance has been reported and studied in some phytophagous mites and 
insects (Van Leeuwen and Dermauw, 2016), and point mutations in GluCls and metabolic detoxification are the main mechanisms associated with abamectin resistance (Dermauw et al., 2012; Kwon et al., 2010a; Kwon et al., 2010b; Mermans et al., 2017; Riga et al., 2014; Stumpf and Nauen, 2002). Two substitutions have been detected in T. urticae: GluCls, G314D in TuGluCl1 and G326E in TuGluCl3, of which the latter was functionally validated in the T. urticae receptor expressed in Xenopus oocytes (Dermauw et al., 2012; Kwon et al., 2010b; Mermans et al., 2017). In addition, Yamaguchi et al. (2012) showed that a G329D substitution in Haemonchus contortus GluCla3B, corresponding to the G314D substitution in TuGluCl1, abolished milbemycin A4 binding, while Wang et al. (2017) showed that a G315E substitution in Plutella xylostella (L.) GluCl, corresponding to G326E in TuGluCl3, reduced sensitivity to abamectin more than 400 -fold. In all populations evaluated by Dermauw et al. (2012), TuGluCl4, and TuGluCl5 genes naturally contained the G326E substitution, regardless of abamectin resistance. Although the substitutions in GluCl1 and GluCl3 were very potent on the level of the receptor, a recent study of Riga et al. (2017) revealed that G314D and G326E lead to only moderate abamectin resistance when introgressed into a susceptible background, suggesting additional resistance mechanisms (Riga et al., 2017). An enhanced metabolism of abamectin has also been associated with resistance. Previous studies suggested that cytochrome P450 monooxygenases (P450s), glutathione S-transferases (GSTs) and carboxylesterase (CarEs) could metabolize abamectin (Kwon et al., 2010a; Riga et al., 2014; Stumpf and Nauen, 2002), although actual metabolism was only shown by Riga et al. (2014) where it was shown that the P450 CYP392A16 metabolizes abamectin. However, Bajda et al. (2015) could not identify the ortholog of CYP392A16 in P. ulmi and Panonychus citri McGregor.

Our previous study indicated that some field-collected P. ulmi populations were resistant to pyrethroid insecticides (Rameshgar et al., 2019), but abamectin resistance in Iranian 
populations of $P$. ulmi has never been studied. Therefore, the aim of this present study was to provide information on the status of susceptibility/resistance of European red mite populations to abamectin. In the identified resistant populations, we determined the occurrence of point mutations in PuGluCl1, PuGluCl2, and PuGluCl3 and evaluated the involvement of metabolic detoxification by using in vivo and in vitro assays.

\section{Materials and methods}

\subsection{Populations of European red mites}

The spirodiclofen selected population (PSR-TK) of P. ulmi is a spirodiclofen-selected laboratory strain that was originally collected in Germany in September 2009, and has been identified as an abamectin susceptible strain (Resistance ratio, $R R=1.7)($ Kramer and Nauen, 2011). Twelve populations of European red mite were collected from commercial apple orchards in Iran during 2016- 2017 and in some of them, resistance to pyrethroids has been characterized previously (Rameshgar et al., 2019). Apple leaf discs were used for the rearing of P. ulmi populations at stable conditions at $25 \pm 1^{\circ} \mathrm{C}$, a photoperiod of 16:8 (light: dark, L: D) h, and $60 \%$ relative humidity $(\mathrm{RH})$.

\subsection{Toxicity and synergism assay}

A commercial formulation of abamectin (EC 10\%, Syngenta, Switzerland) was used for in vivo toxicity tests. Three synergists, piperonyl butoxide (PBO), diethyl maleate (DEM) (Sigma-Aldrich, Bornem, Belgium), and triphenyl phosphate (TPP) (Merck, Darmstadt, Germany) were used for synergism assays.

The method described by Van Leeuwen et al. (2004) was used for toxicity assays in this study. Briefly, the upper side of apple leaf discs $\left(12.25 \mathrm{~cm}^{2}\right)$ was sprayed with different concentrations of abamectin $\left(1.5 \mathrm{~mL}, 1\right.$ bar pressure, $1.46 \pm 0.05 \mathrm{mg}$ spray fluid deposit $\left./ \mathrm{cm}^{2}\right)$ using a Potter spray tower (Burkard Scientific Ltd, Uxbridge, UK), then young adult females of P. ulmi (10-20) were transferred to the upper side of leaf discs. Four replicates of four to 
six concentrations were used, and distilled water served as the control treatment. In synergism assays, apple leaf discs were treated with 1000 , 500, and $1500 \mathrm{mg} \mathrm{L}^{-1}$ concentrations of PBO, DEM, and TPP, respectively. These concentrations of synergists were not toxic to the adult females of $P$. ulmi. After $4 \mathrm{~h}$, mites were tested with abamectin. Mortality was recorded after $24 \mathrm{~h}$. All treated leaf discs were placed in a climatically controlled room at $25 \pm 1{ }^{\circ} \mathrm{C}, 60 \% \mathrm{RH}$ and $16: 8 \mathrm{~h}(\mathrm{~L}: \mathrm{D})$ photoperiod. $\mathrm{LC}_{50}$-values, slopes, resistance ratios (RR), synergistic ratios (SR) and 95\% confidence limits were calculated by using the POLO-Plus software (Robertson et al., 2017).

\subsection{Biochemical assays}

For the determination of carboxylesterase (CarEs) activity in P. ulmi populations, a method previously described by Van Leeuwen et al. (2006) was used, with slight modifications. After preparation of enzyme sources from 50-60 adult female mites, $30 \mu \mathrm{L}$ of enzyme sources were added to each reaction containing $200 \mu \mathrm{L} \alpha$-naphthyl acetate $(64 \mathrm{mM})$, $120 \mu \mathrm{L}$ fast blue RR salt $0.2 \%$, and $200 \mu \mathrm{L}$ sodium phosphate buffer $0.02 \mathrm{M}, \mathrm{pH} 7.3$. Absorbance was recorded every $30 \mathrm{~s}$ for $5 \mathrm{~min}$ at room temperature $\left(25^{\circ} \mathrm{C}\right)$ with a Unico 1200 Spectrophotometer (UNICO, Dayton, USA) at $450 \mathrm{~nm}$.

GST activity in P. ulmi populations was assayed according to Habig et al. (1974). Briefly, $200 \mu \mathrm{L}$ of chloro-dinitro benzene (CDNB) and $200 \mu \mathrm{L}$ of reduced glutathione (10 $\mathrm{mM}$ ) were mixed, then $25 \mu \mathrm{L}$ of enzyme source was added. Finally, absorbance was recorded at $340 \mathrm{~nm}$ every $30 \mathrm{sec}$ for $5 \mathrm{~min}$ at room temperature $\left(25^{\circ} \mathrm{C}\right)$.

P450 activity was estimated by the heme peroxidation method (Brogdon et al., 1997), with slightly modifications. Briefly, the homogenate was diluted to $5.25 \mu \mathrm{g}$ protein $\mathrm{mL}^{-1}$ in potassium phosphate buffer $(0.65 \mathrm{M}, \mathrm{pH} 7.0)$. The reactions mixtures contained $40 \mu \mathrm{L}$ of homogenate, $160 \mu \mathrm{L}$ of potassium phosphate buffer (0.625 M, pH 7.2), $50 \mu \mathrm{L}$ of $\mathrm{H}_{2} \mathrm{O}_{2}(3 \%)$ and $400 \mu \mathrm{L}$ of 3,3'5,5'-tetramethylbenzidine (TMBZ) solution (Sigma Aldrich, USA) and 
after $2 \mathrm{~h}$ incubation at room temperature $\left(25^{\circ} \mathrm{C}\right)$, absorbance was measured at $450 \mathrm{~nm}$ based on Tiwari et al. (2011).

For measuring total protein content, the Bradford method was used with bovine serum albumine as standard (Bradford, 1976). Three replicates were performed for each enzyme and protein measurement. Analysis of variance (ANOVA) followed by LSD mean separation was used to test the differences in the levels of detoxifying enzymes using SAS v. 9.4 (SAS Institute, Cary NC).

\subsection{Molecular assays}

Genomic deoxyribonucleic acid (DNA) was extracted from adult mites (300-400) using the Murray and Thompson method (Murray and Thompson, 1980). The obtained DNA samples were stored at $-10{ }^{\circ} \mathrm{C}$. For the detection of previously described mutations in the target site of abamectin (GluCls), three primer pairs (GluCl1, GluCl2 and GluCl3) were designed for the amplification of P. ulmi GluCls, based on RNA-seq data of Bajda et al. (2015) (Table 1). No primers were designed for P. ulmi GluCl4 and GluCl5 as, like T. urticae, these already contained the glycine to glutamic acid mutation at a position corresponding to G326E of T. urticae GluCl3 (Bajda et al., 2015). PCR reactions were conducted in $50 \mu \mathrm{L}$ final volume with $25 \mu \mathrm{L} 2 \times$ Master mix (Ampliqon, Denmark), $0.6 \mu \mathrm{M}$ of each primer, $3 \mu \mathrm{L}$ DNA, with the following profile: 3 min at $94{ }^{\circ} \mathrm{C}$, followed by 40 cycles of $1 \mathrm{~min}$ at $94{ }^{\circ} \mathrm{C}, 1 \mathrm{~min}$ at $55^{\circ} \mathrm{C}, 1.5 \mathrm{~min}$ at $72{ }^{\circ} \mathrm{C}$ and $10 \mathrm{~min}$ of final extension by using Bio-Rad thermocycler (Bio-Rad Laboratories Inc., Hercules, USA). PCR products of Mahabad population were sequenced by Microsynth (Switzerland) using Sanger sequencing technology, with the same primers as used for PCR. Sequencing data were analyzed using BioEdit 7.0.1 software (Hall, 1999). 


\section{Results}

\subsection{Abamectin toxicity}

Based on the results of abamectin toxicity assays on 13 populations of P. ulmi (Table 2), $\mathrm{LC}_{50}$ values ranged from $0.11 \mathrm{mg}$ a.i. $\mathrm{L}^{-1}$ to $5.50 \mathrm{mg}$ a.i. $\mathrm{L}^{-1}$. The $\mathrm{LC}_{50}$ of the abamectin susceptible PSR-TK population was $0.11 \mathrm{mg}$ a.i. $\mathrm{L}^{-1}$. A relatively high abamectin resistance ratio $(\mathrm{RR}=46)$ was found in the Mahabad population and moderate levels were detected in other populations (RR ranged from 11.5- to 24-fold), when compared to the susceptible strain.

\subsection{Synergism assay}

Pretreatment of PBO resulted in a high level of synergism of abamectin toxicity in the Mahabad population $(\mathrm{SR}=65$-fold), but not in PSR-TK and Shahin Dej populations. Pretreatment with TPP resulted in 2.08-, 4.79- and 8.91-fold synergism in the PSR-TK, Shahin Dej and Mahabad populations, respectively. For the Mahabad population, the second highest synergism of abamectin toxicity was observed with DEM (approx. 22-fold) (Table 3).

\section{3. $\quad$ Mutation detection in GluCls}

The highly resistant Mahabad population was tested for the presence of the previously reported point mutations in GluCls of abamectin resistant two-spotted spider mite. The G314D and G326E substitutions were not observed in PuGluCl1 and PuGluCl3 of the Mahabad population, respectively. Also, at the same position in PuGluCl2 no substitution was detected when compared with the PSR-TK population.

\subsection{Detoxification enzyme activities}

The results of the conducted detoxification enzyme assays are presented in Table 4. The heme peroxidase activity in the Mahabad and Shahin Dej populations was comparable to that of the PSR-TK population. Similarly, the activity of CarEs in Mahabad and Shahin Dej 
populations was not significantly different from the PSR-TK population. GST activity was 1.36-fold increased in the Mahabad population when compared to PSR-TK.

\section{Discussion}

The European red mite P. ulmi causes annual economic damage in Iran, and its control is mainly based on the use of acaricides. Abamectin is one of the most widely used insecticides/ acaricides worldwide (Van Leeuwen et al., 2015). It has an excellent knock-down effect on tetranychid mite species such as P. ulmi (Dybas, 1989). The development of acaricide resistance is in several regions a consequence of frequent applications of acaricides over a long period of time, without proper resistance management (Van Leeuwen et al., 2015; Van Leeuwen et al., 2010). The European red mite is amongst the top 10 of most resistant arthropods, based on the number of active ingredients for which resistance has developed (Van Leeuwen et al., 2015; Michigan State University, 2019).

In the present study, 13 field collected populations of $P$. ulmi were evaluated for the presence of abamectin resistance by a leaf disc spraying method (Van Leeuwen et al., 2004). The bioassay results indicated that the susceptible PSR-TK population shows the lowest $\mathrm{LC}_{50}$ value of $0.11 \mathrm{mg}$ a.i. $\mathrm{L}^{-1}$, a value similar to that reported by Kramer and Nauen (2011). An $\mathrm{LC}_{50}$ value of $0.1 \mathrm{mg} / \mathrm{L}$ is comparable to those found in susceptible populations of $T$. urticae and other phytophagous mites when assessed with comparable methods (Çağatay et al., 2018; Dermauw et al., 2012). The highest level of abamectin resistance was found in the Mahabad population. Our previous work indicated that Mianeh2, Marand and Maraqeh populations were resistant to pyrethroids (Rameshgar et al., 2019). Here, the resistance ratios to abamectin in these populations were 18.26-, 18.87-, and 17.02-fold, respectively. Similar resistance ratios were obtained in Mianeh1 and Salmas populations. In Brazilian populations of T. urticae, abamectin resistance ratios were reported between 2406- and 8272-fold (Monteiro et al., 2015). In a Greek strain of T. urticae, a 1642-fold resistance to abamectin 
was also observed (Riga et al., 2014). In contrast, earlier studies on P. ulmi have never reported such high levels of resistance to abamectin (Knight et al., 1990; Kramer and Nauen, 2011; Nauen et al., 2001). However, in another important species of the Panonychus genus, P. citri, a 153-fold resistance to abamectin was reported from China (Hu et al., 2010).

Two main mechanisms have been described for abamectin resistance in spider mites: enhanced detoxification and target site modification by point mutations (Dermauw et al., 2012; Kwon et al., 2010a; Kwon et al., 2010b; Mermans et al., 2017; Riga et al., 2014; Stumpf and Nauen, 2002; Van Leeuwen and Dermauw, 2016). In contrast to insects, spider mites have several orthologous GluCl genes (Bajda et al., 2015; Dermauw et al., 2012; Van Leeuwen and Dermauw, 2016). A recent study has identified at least five different orthologous GluCl genes in P. ulmi, PuGluCl1, PuGluCl2, PuGluCl3, PuGluCl4, and PuGluCl5 (Bajda et al., 2015). Sequencing of PCR amplified regions of transmembrane domain 3 of GluCls did not identify point mutations previously associated with abamectin resistance (Dermauw et al., 2012; Kwon et al., 2010b; Mermans et al., 2017; Riga et al., 2017). Interestingly, the presence of $\mathrm{GluCl}$ mutations in highly abamectin resistant spider mite strains seems to be variable, with one or both mutations being present in each investigated resistant strain from China, while absent in highly abamectin resistant strains from Turkey or Iran (Çağatay et al., 2018; Memarizadeh et al., 2013; Xu et al., 2018).

Detoxification by metabolism has been suggested as the main abamectin resistance mechanism in mites in other studies (Çağatay et al., 2018; Kwon et al., 2010a; Riga et al., 2014; Stumpf and Nauen, 2002). In the present study, a very high level of synergism was found in Mahabad population $(\mathrm{SR}=64)$ after pretreatment by $\mathrm{PBO}$, while this synergist did not affect abamectin tolerance in the PSR-TK strain. This P450 inhibitor also synergized abamectin toxicity in strain Shahin Dej by 2.60 -fold (Table 3), strongly suggesting P450 based oxidation as a major mechanism. A similar P450-based mechanism of macrolide 
resistance was recently described for ivermectin in the human body louse, Pediculus humanus humanus Linnaeus (Kim et al., 2018). Our synergist data obtained for PBO are not supported by the TMBZ peroxidation assays. This assay measures the total heme content, and hence, moderate overexpression of a single P450 with specificity to abamectin could not be detected in the overall P450 heme-pool. Previous studies have documented that PBO could enhance the toxicity of abamectin in resistant populations of T. urticae (Çağatay et al., 2018; Riga et al., 2014; Stumpf and Nauen, 2002). Over-expression of three cytochrome P450 genes cyp392d8, cyp392d10 and cyp392a16 in an abamectin resistant strain (MR-VP) of T. urticae was confirmed by Dermauw et al. (2013) using full genome microarray analysis and also real-time PCR. Furthermore, overexpression of the P450 gene cyp392a16 was associated with abamectin resistance in T. urticae (Adesanya et al., 2018; Riga et al., 2014; Wu et al., 2019) and it was shown by Riga et al. (2014) that T. urticae CYP392A16 could metabolize abamectin to a less toxic compound. It has been suggested that high levels of abamectin resistance in $T$. urticae could be associated with a synergistic action of P450 detoxification and mutations in GluCls (Riga et al., 2017).

The use of TPP also resulted in a slightly reduced $\mathrm{LC}_{50}$ value of abamectin in the PSRTK population, but a more significant 4.79- and 8.91-fold synergism ratio in Shahin Dej and Mahabad populations, respectively. A similar synergism ratio $(\mathrm{SR}=6.8)$ was reported in a strain of T. urticae from Korea (Kwon et al., 2010a). Treatment of abamectin resistant strains of T. urticae from Turkey with the synergist S-benzyl-O, O-diisopropyl phosphorothioate (IBP) has suggested that CarEs are involved in abamectin resistance (Çağatay et al., 2018). The role of CarEs has also been demonstrated in T. urticae resistance to abamectin (Çağatay et al., 2018; Kwon et al., 2010a).

Synergism assays demonstrated that DEM had no effect on abamectin toxicity in the PSR-TK population, while it showed a high synergism ratio (22.13-fold) in the Mahabad 
population. Involvement of GSTs in abamectin resistance in spider mites was first reported by Stumpf and Nauen (2002). This was confirmed in later studies showing that GSTd14 overexpression is associated with abamectin resistance in other strains (Adesanya et al., 2018; Dermauw et al., 2013; Wu et al., 2019). Furthermore, recombinant expression of TuGSTd14 and subsequent Michaelis-Menten kinetics revealed a competitive type of inhibition by abamectin (Pavlidi et al., 2015).

In conclusion, all field collected populations from apple orchards in Iran were found to be resistant to abamectin, albeit at different levels. Sequencing partial PuGluCl1, PuGluCl2, and PuGluCl3 did not reveal target-site mutations in the most resistant strain. However, full sequencing of GluCls, allowing to identify new mutations, and comparing all strains of $P$. ulmi are needed to further rule out target site resistance as a main mechanism. High synergism levels especially by PBO and DEM imply metabolic resistance mediated by P450s and GSTs as the most likely mechanisms, respectively. The results are helpful in setting up proper resistance management strategies for the control of $P$. ulmi in Iranian apple orchards.

\section{Acknowledgments}

The authors are grateful for financial support of this work by the Research Council of Isfahan University of Technology. The authors would like to thank Bijan Yasaei, Siamak Pakdaman, Omid Abdolahpour, and Manoochehr Mansoori for their help with the collection of P. ulmi populations. This work was partially supported by the Research Council (ERC) under the European Union's Horizon 2020 research and innovation program under Grant Agreement No 772026 (Polyadapt) and Grant Agreement No 773902 (SuperPests). WD is a postdoctoral fellow of the Research Foundation Flanders (FWO). 


\section{References}

Adesanya, A.W., Franco, E., Walsh, D.B., Lavine, M., Lavine, L., Zhu, F., 2018. Phenotypic and Genotypic Plasticity of Acaricide Resistance in Populations of Tetranychus urticae (Acari: Tetranychidae) on Peppermint and Silage Corn in the Pacific Northwest. J. Econ. Entomol. 111, 2831-2843.

Arbabi, M., Kamali, H., Shahrokhi, M. R., 2004. Evaluating fenazaquin 20\% SC new acaricide against Panonychus ulmi Koch in apple orchards of Chenaran of Mashad. Pajouh. Sazan. 61, 51-56.

Bajda, S., Dermauw, W., Greenhalgh, R., Nauen, R., Tirry, L., Clark, R.M., Van Leeuwen, T., 2015. Transcriptome profiling of a spirodiclofen susceptible and resistant strain of the European red mite Panonychus ulmi using strand-specific RNA-seq. BMC Genomics. 16, 974.

Bajda, S., Riga, M., Wybouw, N., Papadaki, S., Ouranou, E., Fotoukkiaii, S.M., Vontas, J., Van Leeuwen, T., 2018. Fitness costs of key point mutations that underlie acaricide target-site resistance in the two spotted spider mite Tetranychus urticae. Evol. Appl. $11,1540-1553$.

Behdad, E., 1991. Fruit Pests. Bahman, Tehran.

Bradford, M.M., 1976. A rapid and sensitive method for the quantitation of microgram quantities of protein utilizing the principle of protein-dye binding. Anal. Biochem. 72, $248-254$.

Brogdon, W.G., McAllister, J.C., Vulule, J., 1997. Heme peroxidase activity measured in single mosquitoes identifies individuals expressing an elevated oxidase for insecticide resistance. J. Am. Mosq. Control Assoc. 13, 233-237.

Çağatay, N.S., Menault, P., Riga, M., Vontas, J., Ay, R., 2018. Identification and characterization of abamectin resistance in Tetranychus urticae Koch populations 
from greenhouses in Turkey. Crop Prot. 112, 112-117.

Dermauw, W., Ilias, A., Riga, M., Tsagkarakou, A., Grbić, M., Tirry, L., Van Leeuwen, T., Vontas, J., 2012. The cys-loop ligand-gated ion channel gene family of Tetranychus urticae: implications for acaricide toxicology and a novel mutation associated with abamectin resistance. Insect Biochem. Mol. Biol. 42, 455-465.

Dermauw, W., Wybouw, N., Rombauts, S., Menten, B., Vontas, J., Grbić, M., Clark, R.M., Feyereisen, R., Van Leeuwen, T., 2013. A link between host plant adaptation and pesticide resistance in the polyphagous spider mite Tetranychus urticae. Proc. Natl. Acad. Sci. U. S. A. 110, E113-E122.

Dybas, R.A., 1989. Abamectin use in crop protection, Ivermectin and abamectin. Springer, pp. 287-310.

Habig, W.H., Pabst, M.J., Jakoby, W.B., 1974. Glutathione S-transferases the first enzymatic step in mercapturic acid formation. J. Biol. Chem. 249, 7130-7139.

Hall, T.A., 1999. BioEdit: a user-friendly biological sequence alignment editor and analysis program for Windows 95/98/NT. Nucleic Acids Symp. Ser, pp. 95-98.

Hu, J., Wang, C., Wang, J., You, Y., Chen, F.J.P.m.s., 2010. Monitoring of resistance to spirodiclofen and five other acaricides in Panonychus citri collected from Chinese citrus orchards. Pest Manage. Sci. 66, 1025-1030.

Jeppson, L.R., Keifer, H.H., Baker, E.W., 1975. Mites injurious to economic plants. Univ of California Press, Berkeley, Los Angeles, USA.

Kim, J., Gellatly, K., Lueke, B., Kohler, M., Nauen, R., Murenzi, E., Yoon, K., Clark, J., 2018. Detoxification of ivermectin by ATP binding cassette transporter C4 and cytochrome P450 monooxygenase 6CJ1 in the human body louse, Pediculus humanus humanus. Insect Mol. Biol. 27, 73-82.

Knight, A., Beers, E., Hoyt, S., Riedl, H., 1990. Acaricide bioassays with spider mites (Acari: 
Tetranychidae) on pome fruits: evaluation of methods and selection of discriminating concentrations for resistance monitoring. J. Econ. Entomol. 83, 1752-1760.

Kramer, T., Nauen, R., 2011. Monitoring of spirodiclofen susceptibility in field populations of European red mites, Panonychus ulmi (Koch)(Acari: Tetranychidae), and the crossresistance pattern of a laboratory-selected strain. Pest Manage. Sci. 67, 1285-1293.

Kwon, D.H., Seong, G.M., Kang, T.J., Lee, S.H., 2010a. Multiple resistance mechanisms to abamectin in the two-spotted spider mite. J. Asia-Pac. Entomol. 13, 229-232.

Kwon, D.H., Yoon, K.S., Clark, J.M., Lee, S.H., 2010b. A point mutation in a glutamate gated chloride channel confers abamectin resistance in the two spotted spider mite, Tetranychus urticae Koch. Insect Mol. Biol. 19, 583-591.

Memarizadeh, N., Ghadamyari, M., Zamani, P., Sajedi, R.H., 2013. Resistance mechanisms to abamectin in Iranian populations of the two-spotted spider mite, Tetranychus urticae Koch (Acari: Tetranychidae). Acarologia 53, 235-246.

Mermans, C., Dermauw, W., Geibel, S., Van Leeuwen, T., 2017. A G326E substitution in the glutamate gated chloride channel $3(\mathrm{GluCl} 3)$ of the two spotted spider mite Tetranychus urticae abolishes the agonistic activity of macrocyclic lactones. Pest Manage. Sci. 73, 2413-2418.

Michigan State University, n.d. Arthropod pesticide resistance database [WWW Document]. URL https://www.pesticideresistance.org/display.php?page=species\& $\operatorname{arId}=536$ (accessed 12.5.19).

Monteiro, V.B., Gondim Jr, M.G., Oliveira, J.E.d.M., Siqueira, H.A., Sousa, J.M., 2015. Monitoring Tetranychus urticae Koch (Acari: Tetranychidae) resistance to abamectin in vineyards in the Lower Middle São Francisco Valley. Crop Prot. 69, 90-96.

Murray, M.G., Thompson, W.F., 1980. Rapid isolation of high molecular weight plant DNA. Nucleic Acids Res. 8, 4321-4326. 
Nauen, R., Stumpf, N., Elbert, A., Zebitz, C.P.W., Kraus, W., 2001. Acaricide toxicity and resistance in larvae of different strains of Tetranychus urticae and Panonychus ulmi (Acari: Tetranychidae). Pest Manage. Sci. 57, 253-261.

Ozoe, Y., 2013. $\gamma$-Aminobutyrate-and glutamate-gated chloride channels as targets of insecticides, Adv. Insect Physiol. Elsevier, pp. 211-286.

Pavlidi, N., Tseliou, V., Riga, M., Nauen, R., Van Leeuwen, T., Labrou, N.E., Vontas, J., 2015. Functional characterization of glutathione S-transferases associated with insecticide resistance in Tetranychus urticae. Pestic. Biochem. Physiol. 121, 53-60.

Rameshgar, F., Khajehali, J., Nauen, R., Bajda, S., Jonckheere, W., Dermauw, W., Van Leeuwen, T., 2019. Point mutations in the voltage-gated sodium channel gene associated with pyrethroid resistance in Iranian populations of the European red mite Panonychus ulmi. Pestic. Biochem. Physiol. 157, 80-87.

Riga, M., Bajda, S., Themistokleous, C., Papadaki, S., Palzewicz, M., Dermauw, W., Vontas, J., Van Leeuwen, T.J.S.R., 2017. The relative contribution of target-site mutations in complex acaricide resistant phenotypes as assessed by marker assisted backcrossing in Tetranychus urticae. Sci. Rep. 7, 9202.

Riga, M., Tsakireli, D., Ilias, A., Morou, E., Myridakis, A., Stephanou, E., Nauen, R., Dermauw, W., Van Leeuwen, T., Paine, M., 2014. Abamectin is metabolized by CYP392A16, a cytochrome P450 associated with high levels of acaricide resistance in Tetranychus urticae. Insect Biochem. Mol. Biol. 46, 43-53.

Robertson, J.L., Jones, M.M., Olguin, E., Alberts, B., 2017. Bioassays with arthropods. CRC press, Boca Raton, Florida, US.

Sparks, T.C., Nauen, R., 2015. IRAC: Mode of action classification and insecticide resistance management. Pestic. Biochem. Physiol. 121, 122-128.

Stumpf, N., Nauen, R., 2002. Biochemical markers linked to abamectin resistance in 
Tetranychus urticae (Acari: Tetranychidae). Pestic. Biochem. Physiol. 72, 111-121.

Tiwari, S., Mann, R.S., Rogers, M.E., Stelinski, L.L., 2011. Insecticide resistance in field populations of Asian citrus psyllid in Florida. Pest. Manag. Sci. 67, 1258e1268.

Van Leeuwen, T., Dermauw, W., 2016. The molecular evolution of xenobiotic metabolism and resistance in chelicerate mites. Annu. Rev. Entomol. 61, 475-498.

Van Leeuwen, T., Dermauw, W., Grbic, M., Tirry, L., Feyereisen, R., 2013. Spider mite control and resistance management: does a genome help? Pest Manage. Sci. 69, 156159.

Van Leeuwen, T., Stillatus, V., Tirry, L., 2004. Genetic analysis and cross-resistance spectrum of a laboratory-selected chlorfenapyr resistant strain of two-spotted spider mite (Acari: Tetranychidae). Exp. Appl. Acarol. 32, 249.

Van Leeuwen, T., Tirry, L., Yamamoto, A., Nauen, R., Dermauw, W., 2015. The economic importance of acaricides in the control of phytophagous mites and an update on recent acaricide mode of action research. Pestic. Biochem. Physiol. 121, 12-21.

Van Leeuwen, T., Van Pottelberge, S., Tirry, L., 2006. Biochemical analysis of a chlorfenapyr selected resistant strain of Tetranychus urticae Koch. Pest Manage. Sci. $62,425-433$.

Van Leeuwen, T., Vontas, J., Tsagkarakou, A., Dermauw, W., Tirry, L., 2010. Acaricide resistance mechanisms in the two-spotted spider mite Tetranychus urticae and other important Acari: a review. Insect Biochem. Mol. Biol. 40, 563-572.

Wang, X., Puinean, A.M., Williamson, M.S., Smelt, C.L., Millar, N.S., Wu, Y., 2017. Mutations on M3 helix of Plutella xylostella glutamate-gated chloride channel confer unequal resistance to abamectin by two different mechanisms. Insect Biochem. Mol. Biol. 86, 50-57.

Wang, X., Williamson, M.S., Puinean, A.M., Yang, Y., Wu, S., Wu, Y., 2019. Function and 
pharmacology of glutamate-gated chloride channel exon 9 splice variants from the diamondback moth Plutella xylostella. Insect Biochem. Mol. Biol. 104, 58-64.

Whalon, M., Mota-Sanchez, D., Hollingworth, R., Duynslager, L., 2012. Arthropod pesticide resistance database. Michigan State University. On-line at: www. pesticideresistance. org 38 .

Wolstenholme, A., Rogers, A., 2005. Glutamate-gated chloride channels and the mode of action of the avermectin/milbemycin anthelmintics. Parasitology 131, S85-S95.

Wolstenholme, A.J., 2010. Recent progress in understanding the interaction between avermectins and ligand-gated ion channels: putting the pests to sleep. Invertebr. Neurosci. 10, 5-10.

Wolstenholme, A.J., 2012a. Glutamate-gated chloride channels. J. Biol. Chem. 287, 4023240238.

Wolstenholme, A.J., 2012b. Surviving in a toxic world. Science. 335, 545-546.

Wu, M., Adesanya, A.W., Morales, M.A., Walsh, D.B., Lavine, L.C., Lavine, M.D., Zhu, F., 2019. Multiple acaricide resistance and underlying mechanisms in Tetranychus urticae on hops. J. Pest Sci. 92, 543-555.

Xu, D., He, Y., Zhang, Y., Xie, W., Wu, Q., Wang, S., 2018. Status of pesticide resistance and associated mutations in the two-spotted spider mite, Tetranychus urticae, in China. Pestic. Biochem. Physiol. 150, 89-96.

Yamaguchi, M., Sawa, Y., Matsuda, K., Ozoe, F., Ozoe, Y., 2012. Amino acid residues of both the extracellular and transmembrane domains influence binding of the antiparasitic agent milbemycin to Haemonchus contortus AVR-14B glutamate-gated chloride channels. Biochem. Biophys. Res. Commun. 419, 562-566. 


\begin{tabular}{lllll}
\hline Target & Mutation & Fragment size & Primer name & Sequence $\left(5^{\prime}-3^{\prime}\right)$ \\
\hline \multirow{2}{*}{ PuGluCl1 } & G314D & 534 & GluCl1-F & ATAGTTGCCTCAAAGTGGAA \\
& & & GluCl1-R & TGGATCTTGTCGTGAATCTTG \\
PuGluCl2 & - & GluCl2-F & GAAAGATGGTGACCCTGTAC \\
& & 490 & GluCl2-R & AACGTTACCATCTTTATCCC \\
PuGluCl3 & G326E & 537 & GluCl3-F & ACAGTTGTGTCCAAGTAAAG \\
& & & GluCl3-R & GAAGTGGTTGATGTGGTTCC \\
\hline
\end{tabular}

Table 1

List of primers used for specific amplification of GluCls in P. ulmi 


\begin{tabular}{|c|c|c|c|c|c|c|}
\hline Population & $\mathrm{n}^{\mathrm{a}}$ & $\begin{array}{l}\mathrm{LC}_{50} \mathrm{mg} \text { a.i. } \mathrm{L}^{-1} \\
(\mathrm{CI} 95 \%)^{\mathrm{c}}\end{array}$ & $\begin{array}{l}\mathrm{LC}_{95} \mathrm{mg} \text { a.i. } \mathrm{L}^{-1} \\
(\mathrm{CI} 95 \%)^{\mathrm{c}}\end{array}$ & Slope \pm SE & $\chi^{2}(\mathrm{df})$ & $\begin{array}{l}\mathrm{RR}^{\mathrm{b}} \\
(\mathrm{CI} 95 \%)^{\mathrm{c}}\end{array}$ \\
\hline PSR-TK & 150 & $0.11(0.05-0.18)$ & $1.10(0.57-4.95)$ & $1.70 \pm 0.39$ & $0.92(3)$ & - \\
\hline Shahin Dej & 314 & $1.57(1.27-1.89)$ & $6.88(4.68-11.15)$ & $2.56 \pm 0.33$ & $2.81(3)$ & $15.00(8.04-27.98)$ \\
\hline Mahabad & 278 & $5.50(3.16-9.24)$ & $43.85(20.38-325.11)$ & $1.82 \pm 0.26$ & $5.76(4)$ & $46.13(25.70-82.79)$ \\
\hline Mianeh1 & 194 & $2.61(1.97-3.38)$ & $12.68(7.94-33.42)$ & $2.39 \pm 0.46$ & $1.46(3)$ & $24.05(12.69-45.56)$ \\
\hline Ahar & 323 & $1.61(1.10-2.41)$ & $10.56(5.84-42.15)$ & $2.01 \pm 0.25$ & $3.85(3)$ & $11.45(6.67-19.66)$ \\
\hline Semirom 1 & 309 & $1.61(1.27-1.89)$ & $3.54(2.92-4.87)$ & $4.80 \pm 0.83$ & $1.53(3)$ & $13.48(7.81-23.26)$ \\
\hline Semirom2 & 291 & $1.92(1.47-2.23)$ & $3.91(3.26-5.63)$ & $5.32 \pm 1.13$ & $1.56(3)$ & $16.90(9.74-29.32)$ \\
\hline Urmia & 285 & $1.78(1.02-2.70)$ & $10.57(5.81-44.42)$ & $2.13 \pm 0.26$ & $4.19(3)$ & $15.18(8.08-28.55)$ \\
\hline Salmas & 249 & $2.50(2.03-3.07)$ & $11.42(7.89-21.17)$ & $2.49 \pm 0.35$ & $1.34(3)$ & $22.67(12.41-41.42)$ \\
\hline Marand & 254 & $2.25(0.82-3.56)$ & $13.93(7.03-147.67)$ & $2.08 \pm 0.66$ & $1.91(3)$ & $18.87(8.93-39.88)$ \\
\hline Maraqeh & 255 & $1.99(1.52-2.54)$ & $12.28(7.93-25.96)$ & $2.08 \pm 0.30$ & $0.99(3)$ & $17.02(8.95-32.36)$ \\
\hline Mianeh2 & 241 & $2.79(2.12-3.72)$ & $21.63(12.27-62.93)$ & $1.85 \pm 0.31$ & $1.32(3)$ & $18.26(5.37-62.00)$ \\
\hline Khafr & 312 & $1.39(1.02-1.81)$ & $6.28(3.79-20.33)$ & $2.52 \pm 0.25$ & $5.95(3)$ & $11.68(6.82-20.02)$ \\
\hline
\end{tabular}

\footnotetext{
${ }^{\mathrm{a}}$ Number of mites tested.

${ }^{\mathrm{b}}$ Resistance ratio $=\mathrm{LC}_{50} / \mathrm{LC}_{50}$ PSR-TK.

${ }^{\mathrm{c}}$ Confidence interval.
}

\section{Table 2}

Log-dose probit-mortality data for abamectin tested against the adult females of P. ulmi field populations and PSR-TK population. 


\begin{tabular}{|c|c|c|c|c|c|c|}
\hline Population & Treatment & $\mathrm{n}^{\mathrm{a}}$ & $\begin{array}{l}\mathrm{LC}_{50} \mathrm{mg} \text { a.i. } \mathrm{L}^{-1} \\
(\mathrm{CI} 95 \%)^{\mathrm{c}}\end{array}$ & Slope \pm SE & $\chi 2(\mathrm{df})$ & $\begin{array}{l}\mathrm{SR}^{\mathrm{b}} \\
(\mathrm{CI} 95 \%)^{\mathrm{c}}\end{array}$ \\
\hline \multirow[t]{4}{*}{ PSR-TK } & abamectin & 150 & $0.11(0.69-0.18)$ & $1.70 \pm 0.39$ & $0.92(3)$ & - \\
\hline & Abamectin + PBO & 123 & $0.07(0.04-0.10)$ & $2.48 \pm 0.65$ & $0.59(3)$ & $1.66(0.85-3.35)$ \\
\hline & Abamectin + TPP & 109 & $0.05(0.03-0.10)$ & $1.67 \pm 0.49$ & $0.74(3)$ & $2.08(1.00-4.34)$ \\
\hline & Abamectin + DEM & 126 & $0.09(0.05-0.15)$ & $2.58 \pm 0.75$ & $1.17(3)$ & $1.21(0.59-2.47)$ \\
\hline \multirow[t]{4}{*}{ Shahin Dej } & abamectin & 314 & $1.57(1.27-1.89)$ & $2.56 \pm 0.33$ & $2.81(3)$ & - \\
\hline & Abamectin + PBO & 115 & $0.70(0.41-0.96)$ & $2.51 \pm 0.66$ & $2.05(3)$ & $2.60(1.50-3.39)$ \\
\hline & Abamectin + TPP & 125 & $0.37(0.21-0.61)$ & $1.68 \pm 0.48$ & $1.69(3)$ & $4.79(2.57-8.94)$ \\
\hline & Abamectin + DEM & 109 & $0.67(0.37-1.24)$ & $2.09 \pm 0.61$ & $1.69(3)$ & $2.33(1.36-3.99)$ \\
\hline \multirow[t]{4}{*}{ Mahabad } & abamectin & 278 & $5.50(3.16-9.24)$ & $1.82 \pm 0.26$ & $5.76(4)$ & - \\
\hline & Abamectin $+\mathrm{PBO}$ & 217 & $0.09(0.05-0.283)$ & $0.65 \pm 0.15$ & $8.04(6)$ & $64.99(24.28-173.91)$ \\
\hline & Abamectin + TPP & 117 & $0.47(0.21-1.01)$ & $2.25 \pm 0.43$ & $3.67(3)$ & $8.91(6.03-13.17)$ \\
\hline & Abamectin + DEM & 122 & $0.19(0.05-0.33)$ & $1.16 \pm 0.33$ & $1.25(3)$ & $22.13(10.34-47.34)$ \\
\hline
\end{tabular}

\footnotetext{
${ }^{a}$ Number of mites tested.

${ }^{\mathrm{b}}$ Synergistic ratio.

${ }^{\mathrm{c}}$ Confidence interval.
}

\section{Table 3}

Synergistic effect of PBO (1000 mg L $\left.{ }^{-1}\right)$, TPP $\left(1500 \mathrm{mg} \mathrm{L}^{-1}\right)$, and DEM (500 $\left.\mathrm{mg} \mathrm{L}^{-1}\right)$ on abamectin resistance in $P$. ulmi populations, compared to the PSR-TK population. 


\begin{tabular}{llclllc}
\hline Population & $\begin{array}{l}\text { P450s } \\
\text { TMBZ }\end{array}$ & Ratio & $\begin{array}{l}\text { GSTs } \\
\text { CDNB conjugation }\end{array}$ & Ratio $^{\mathrm{d}}$ & $\begin{array}{l}\text { CarEs } \\
\alpha \text {-Naphthyl Acetate }^{\mathrm{c}}\end{array}$ & Ratio $^{\mathrm{d}}$ \\
\hline PSR-TK & $8.67 \pm 0.23^{\mathrm{a}}$ & - & $553.74 \pm 27^{\mathrm{b}}$ & - & $4116.63 \pm 180^{\mathrm{a}}$ & - \\
Shahin Dej & $8.35 \pm 0.42^{\mathrm{a}}$ & 0.96 & $459.05 \pm 18^{\mathrm{c}}$ & 0.82 & $3766.11 \pm 197^{\mathrm{a}}$ & 0.91 \\
Mahabad & $9.09 \pm 0.30^{\mathrm{a}}$ & 1.04 & $756.27 \pm 12^{\mathrm{a}}$ & 1.36 & $4138.38 \pm 347^{\mathrm{a}}$ & 1.00 \\
& $\mathrm{~F}_{2,8}=1.07, P=0.399>0.05$ & $\mathrm{~F}_{2,8}=55.77, P=0.0001<0.05$ & $\mathrm{~F}_{2,8}=0.68, P=0.542>0.05$ \\
\hline
\end{tabular}

${ }^{a}$ equivalent units of cytochrome $\mathrm{P} 450 \mathrm{mg}^{-1}$ protein $( \pm \mathrm{SEM})$.

${ }^{\mathrm{b}}$ nmol glutathione conjugated $\mathrm{min}^{-1} \mathrm{mg}^{-1}$ protein $( \pm \mathrm{SEM})$.

${ }^{\mathrm{c}}$ nmol 1-naphthol $\mathrm{min}^{-1} \mathrm{mg}^{-1}$ protein $( \pm \mathrm{SEM})$

${ }^{\mathrm{d}}$ Enzyme activity resistant population/enzyme activity PSR-TK population.

Significant differences are indicated by different letters within the columns (one-way ANOVA, $p<0$. 05; LSD test).

\section{Table 4}

Detoxification enzyme activities in different populations of $P$. ulmi (mean $\pm \mathrm{SEM}$ ). 